\title{
HEALTH DYNAMICS OF THE MEDICAL UNIVERSITY STUDENTS DURING SPORTS ACTIVITIES
}

D0l:10.36740/WLek202102123

\author{
Iryna M. Melnychuk', Svitlana 0. Yastremska' ', Dariya V. Popovych'', Vasyl V. Humeniuk², Oksana V. Yefremova², \\ Liubov V. Novakova' ${ }^{1}$ Oksana V. Shukatka ${ }^{3}$ \\ II. HORBACHEVSKY TERNOPIL NATIONAL MEDICAL UNIVERSITY, TERNOPIL, UKRAINE \\ 2DANYLO HALYTSKY LVIV NATIONAL MEDICAL UNIVERSITY, LVIV, UKRAINE \\ IIVAN FRANKO NATIONAL UNIVERSITY OF LVIV, LVIV, UKRAINE
}

\begin{abstract}
The aim: Is to investigate the dynamics of the morphofunctional development and physical health of students who were engaged in strength sports while studying at university. Materials and methods: The study involved 360 male students of different faculties between the ages of 17 and 20 . Two groups of students were formed: experimental and control groups. The EG students ( $n=40$ ) were engaged in strength sports (powerlifting, athletics, Crossfit); the $(G$ students ( $n=320)$ were training according to the current program of physical education. The study of the morphofunctional development of students was carried out taking account of the indicators of body length, body weight, handgrip test, heart rate, blood pressure, and vital capacity. The level of students' health was examined according to the methodology of the assessment of the physical health level by G. L. Apanasenko.

Results: It was established that strength sports at university affect physical development, functional abilities of the major systems of an organism, and the health state of future doctors in a more efficient way than the current program of physical education. It was found that the influence on the indicators of handgrip test, vital capacity, and heart rate of the EG students was the most prominent positive effect of sports. The evaluation of the calculated indexes (power index, life index) and the level of physical health confirmed this trend.

Conclusions: The conducted research asserts the necessity of introducing the sports-oriented form of the physical training organization at the medical higher education institutions of Ukraine to strengthen the students' health and to maintain the efficiency of the future doctors' professional activity.
\end{abstract}

KEY WORDS: health, sport, physical education, students

Wiad Lek. 2021;74(2):295-302

\section{INTRODUCTION}

The system of modern medical higher education is aimed at training a highly qualified specialist who is able to perform significant amounts of work without reducing the quality and intensity and must have a high level of psychomotor qualities that reflects the requirements for physical and mental health, physical fitness and working efficiency of students, future doctors $[1,2]$. However, the analysis of the scientists' research results $[3,4,5]$ showed a low level of physical fitness of most modern students and a constant increase in the number of people with impaired health both at the beginning and in the process of studying at Ukrainian higher education institutions (HEI).

It is generally accepted that human health is the exclusive competence of health authorities. However, it is a known fact that medical sciences study the diagnosis of diseases, the treatment process, and the means of disease prevention. Many other sciences, including physical education, solve the problems of health promotion, physical and mental development, study the problems aimed at expanding the functional capabilities of students $[6,7,8]$.
The works of scientists $[9,10]$ note that the biological age of the students between the ages of 20 and 24 gets ahead of the stated age by 10-15 years. The studies of G. L. Apanasenko [11] determine that the share of the male population in the "safe zone" of health has decreased from 8 to $1 \%$ over the last 20 years in Ukraine. The works of other scientists $[13,14]$ mention that the number of students with low and below the middle level of somatic health increased from $60 \%$ in 2009 to $85 \%$ in 2019 . The scientists $[15,16]$ point out that some factors of life and socially hygienic living conditions, as well as studying at HEI do not provide optimal health for students. As a result of students testing, scientists [17] defined the initial level of physical fitness of the first-year students, among whom $18 \%$ showed a low level; $49 \%$ - lower than the middle (unsatisfactory grade); $20 \%$ - the middle level (satisfactory grade); $13 \%$ - above the middle (good grade). No students with a high level of physical fitness were found.

The research many scientists $[17,18]$ notes that a significant part of student does not reach even the middle level of physical fitness during the study that indicates a low effi- 
ciency of the physical education system in Ukraine. Among the main reasons for the decrease in the physical fitness of students, the authors highlight the lack of health-promoting and training orientation of the forms and means of physical education, low motor activity of students, the lack of interests, motives, and needs for physical exercises, etc. $[19,20]$. Some studies $[21,22]$ also mention that the decline in the health indicators of students goes back to the health of school students and university applicants. The basics of health should be laid at school age, however, according to scientists, the number of healthy school graduates accounts for 5-25\%, more than $50 \%$ of them have unsatisfactory physical fitness, $90 \%$ of school graduates have health problems.

The World Health Organization defined approximate ratios of various factors that ensure and form the health of modern people, namely: genetic factors (heredity) -20 $\%$, the state of the environment (climate, environmental circumstances) - $20 \%$, the level of health care (medical care) $-8 \%$, living conditions and lifestyle (rational work, physical activity, nutrition, personal hygiene, rejection of bad habits) - $52 \%$ [23]. According to many scientists [14, $15,24]$, the conditions and way of life, with various elements that relate to all aspects of health - physical, mental, social, and spiritual, are the key elements of improving the health and efficiency of students.

Physical exercises are of great importance for health promotion and disease prevention $[18,20,25]$. World experience shows that the physical activity of a person throughout life prevents diseases and improves health. However, according to scientists $[3,4,10]$, the difficult economic situation, developed in Ukraine in the post-Soviet period, negatively affected the development of physical education and mass sports at HEI. Every year the number of students training in special medical groups is steadily growing, the number of healthy students is decreasing. Scientists note that under such conditions, the formation of a healthy lifestyle, and the involvement of young students in regular exercises and sports should become one of the important areas of the HEI's activities. Scientists [18, $20,26]$ consider the introduction of a sports-oriented form of physical education of students taking into account the students' sports choice a promising direction for improving the system of physical education at HEI. At the same time, the popularity of the sport among students, the possibilities of the educational and sports base of HEI, and the specialists among the teaching staff of the Department of Physical Education should be taken into account.

\section{THE AIM}

The aim is to investigate the dynamics of the morphofunctional development and physical health of students who were involved in strength sports while studying at university.

\section{MATERIALS AND METHODS}

The study of the morphofunctional development and physical health of students was conducted at I. Horbachevsky
Ternopil National Medical University (Ukraine) in 20182020. The study involved 360 male students of different faculties between the ages of 17 and 20. Two groups of students were formed: an EG $(n=40)$ and a CG $(n=320)$. The EG students belonged to the sports educational department and were engaged in such strength sports as powerlifting, athletics, Crossfit in specialized sports clubs at university. The CG students belonged to the main educational department and were training according to the current program of physical education. To investigate the morphofunctional development of university students, we analyzed the following indicators: body length, body weight, handgrip test, heart rate, systolic and diastolic blood pressure, and vital capacity. The level of students' health was examined according to the methodology of the assessment of the physical health level by Professor G. L. Apanasenko [11]. The health level was evaluated in points and it included the estimation of the body mass index (BMI - the ratio of body weight to body length), life index (LI - the ratio of vital capacity to body weight), Robinson's index (RI - a product of heart rate and systolic blood pressure), power index (PI - the ratio of the indicators of handgrip test to body weight) and heart rate recovery (HRR) after a standard exercise (20 squats in $30 \mathrm{sec}$ ) (Table I). The research was conducted in the 1st - 4th terms of study. Medical examinations were conducted by the doctors of medical center of the university.

The methods of investigation: analysis and generalization of the scientific and methodological literature, observation, pedagogical testing, medical and biological methods, and methods of mathematical statistics. The authenticity of the difference between the indicators of students of EG and CG was determined by Student's t-test and the dynamics of the indicators during studying were examined.

\section{RESULTS}

The analysis of the students' body length showed that a significant difference between the indicators of the EG and CG was not detected at all stages of the study ( $>>0.05)$. During the 1st and 2nd years of study, the body length of students in both groups increased, but no significant difference between the indicators of the 1 st and 2 nd years was found ( $p>0.05)$ (Table II). This indicates that both classes according to the current program of physical education at medical universities, and classes in the specialized sports clubs of strength sports do not affect the body length of the HEI students significantly.

The study of the body weight dynamics shows that in the 1st - 3rd terms of study, the indicators of the EG and CG students did not differ significantly $(\mathrm{p}>0.05)$. In the 4th term, the body weight of the EG students was significantly lower than that of the CG students by $2.9 \mathrm{~kg}(\mathrm{p}>0.05)$. A comparative analysis of the students' body weight at the beginning and at the end of the study showed that it increased significantly by $3.7 \mathrm{~kg}$ in the CG $(\mathrm{p}<0.001)$ and did not change authentically in the EG ( $p>0.05)$ (Table II). It proves the positive impact of sports 
Table I. The physical health level evaluation according to the methodology by G. L. Apanasenko (male, points)

\begin{tabular}{|c|c|c|c|c|c|}
\hline \multirow{2}{*}{ The indicators investigated } & \multicolumn{5}{|c|}{ The level of physical health } \\
\hline & Low & Below the middle & Middle & Above the middle & High \\
\hline $\mathrm{BMI}, \mathrm{kg} / \mathrm{m}^{2}$ & $18.9 \mathrm{i}<$ & $19.0-20.0$ & $20.1-25.0$ & $25.1-28.0$ & $28.1 \mathrm{i}>$ \\
\hline Numerical score & -2 & -1 & 0 & & \\
\hline $\mathrm{LI}, \mathrm{ml} / \mathrm{kg}$ & $50 i<$ & $51-55$ & $56-60$ & $61-65$ & $66 i>$ \\
\hline Numerical score & -1 & 0 & 1 & 2 & 3 \\
\hline $\mathrm{PI}, \%$ & $60 i<$ & $61-65$ & $66-70$ & $71-80$ & $81 \mathrm{i}>$ \\
\hline Numerical score & -1 & 0 & 1 & 2 & 3 \\
\hline RI, s.u. & $111 \mathrm{i}>$ & $95-110$ & $85-94$ & $70-84$ & $69 i<$ \\
\hline Numerical score & -2 & -1 & 0 & 3 & 5 \\
\hline HRR, sec & $180 \mathrm{i}>$ & $120-180$ & $90-120$ & $60-90$ & $59 \mathrm{i}<$ \\
\hline Numerical score & -2 & 1 & 3 & 5 & 7 \\
\hline The amount of points & $3 i<$ & $4-6$ & $7-11$ & $12-15$ & $16-18$ \\
\hline
\end{tabular}

Table II . Comparative characteristics of the EG and CG students' physical development indicators while studying at a medical university (Mean \pm SD)

\begin{tabular}{|c|c|c|c|}
\hline Terms of study & EG $(n=40)$ & CG $(n=320)$ & Significance value \\
\hline \multicolumn{4}{|c|}{ Body length, $\mathrm{cm}$} \\
\hline $1 \mathrm{st}$ & $176.1 \pm 1.25$ & $175.9 \pm 0.77$ & $p>0.05$ \\
\hline 2nd & $176.4 \pm 1.24$ & $176.3 \pm 0.75$ & $p>0.05$ \\
\hline $3 r d$ & $176.5 \pm 1.24$ & $176.4 \pm 0.74$ & $p>0.05$ \\
\hline 4 th & $176.9 \pm 1.23$ & $176.5 \pm 0.72$ & $p>0.05$ \\
\hline \multicolumn{4}{|c|}{ Body weight, kg } \\
\hline $1 \mathrm{st}$ & $72.7 \pm 1.36$ & $72.5 \pm 0.59$ & $p>0.05$ \\
\hline 2nd & $73.1 \pm 1.41$ & $73.8 \pm 0.45$ & $p>0.05$ \\
\hline $3 r d$ & $73.2 \pm 1.28$ & $75.0 \pm 0.52$ & $p>0.05$ \\
\hline 4th & $73.3 \pm 1.29$ & $76.2 \pm 0.54$ & $\mathrm{p}<0.05$ \\
\hline \multicolumn{4}{|c|}{ Handgrip test, kg } \\
\hline $1 \mathrm{st}$ & $38.9 \pm 1.20$ & $38.6 \pm 0.72$ & $p>0.05$ \\
\hline 2nd & $41.3 \pm 1.18$ & $39.5 \pm 0.68$ & $p>0.05$ \\
\hline $3 r d$ & $43.2 \pm 1.16$ & $39.9 \pm 0.65$ & $\mathrm{p}<0.05$ \\
\hline 4th & $46.5 \pm 1.15$ & $40.4 \pm 0.66$ & $p<0.001$ \\
\hline \multicolumn{4}{|c|}{ Vital capacity, ml } \\
\hline $1 \mathrm{st}$ & $3982.4 \pm 97.11$ & $3960.7 \pm 52.13$ & $p>0.05$ \\
\hline 2nd & $4144.1 \pm 96.84$ & $4038.3 \pm 48.20$ & $p>0.05$ \\
\hline $3 r d$ & $4295.9 \pm 92.58$ & $4097.5 \pm 47.74$ & $p>0.05$ \\
\hline 4th & $4427.3 \pm 89.30$ & $4155.4 \pm 47.22$ & $\mathrm{p}<0.05$ \\
\hline
\end{tabular}

Legend: Mean - arithmetical average; SD - standard deviation; $p$ - the significance of difference between the indicators of EG and CG due to the Student's t-test

on the physical development of medical students. The established trend of the CG students' weight gain shows that the current conditions of studying at HEI, which are characterized by large amounts of educational material, long-lasted staying in classrooms in a position, low motor activity, nervous and emotional stress, especially during exams sessions, lead to the body weight gain. At the same time, classes according to the current methodology for physical education do not effectively influence the stabilization of students' body weight. The body weight of the students who regularly attend specialized clubs in strength sports at university remains stable during the period of study.

The study of the handgrip test showed that the strength of the arm muscles of the students of both groups did not differ significantly in the 1 st and 2 nd terms of study ( $p>0.05)$ (Table II). The indicators of the EG students' handgrip test started to exceed significantly the indicators of the CG students from the $3 \mathrm{rd}$ term: by $3.3 \mathrm{~kg}$ in the $3 \mathrm{rd}$ term $(\mathrm{p}<0.05)$ and by $6.1 \mathrm{~kg}$ in the 4 th $(\mathrm{p}<0.001)$. During 
Table III. Comparative characteristics of the EG and CG students' functional state indicators while studying at a medical university (Mean \pm SD)

\begin{tabular}{cccc}
\hline Terms of study & EG $(\mathbf{n}=\mathbf{4 0})$ & CG $(\mathbf{n}=\mathbf{3 2 0})$ & Significance value \\
\hline & \multicolumn{1}{c}{ Heart rate at rest, beats/min } & $70.9 \pm 0.52$ & $\mathrm{p}>0.05$ \\
\hline 1st & $71.0 \pm 1.15$ & $70.9 \pm 0.51$ & $\mathrm{p}>0.05$ \\
\hline 2nd & $69.6 \pm 1.13$ & $71.2 \pm 0.53$ & $\mathrm{p}>0.05$ \\
\hline 3rd & $69.3 \pm 1.12$ & $71.3 \pm 0.53$ & $\mathrm{p}<0.05$ \\
\hline 4th & $68.7 \pm 1.10$ & Systolic blood pressure, mmHg & $\mathrm{p}>0.05$ \\
\hline 1st & $120.2 \pm 1.09$ & $120.1 \pm 0.42$ & $\mathrm{p}>0.05$ \\
\hline 2nd & $120.1 \pm 1.06$ & $120.0 \pm 0.42$ & $\mathrm{p}>0.05$ \\
\hline 3rd & $119.9 \pm 1.06$ & $120.2 \pm 0.41$ & $\mathrm{p}>0.05$ \\
\hline 4th & $119.8 \pm 1.05$ & $120.2 \pm 0.42$ & $\mathrm{p}$ \\
\hline 1st & Diastolic blood pressure, $\mathrm{mmHg}$ & $\mathrm{p}>0.05$ \\
\hline 2nd & $70.5 \pm 0.63$ & $70.9 \pm 0.37$ & $\mathrm{p}>0.05$ \\
\hline 3rd & $70.2 \pm 0.62$ & $70.8 \pm 0.36$ & $\mathrm{p}>0.05$ \\
\hline 4th & $69.8 \pm 0.60$ & $70.7 \pm 0.36$ & $\mathrm{p}>0.05$ \\
\hline
\end{tabular}

Legend:Mean - arithmetical average;SD - standard deviation; $\mathrm{p}$ - the significance of difference between the indicators of $\mathrm{E}$ and $\mathrm{G}$ due to the Student'st-test

the research, the muscle strength of the students of both groups increased, but indicators improved significantly in the EG $(\mathrm{p}<0.001)$, and insignificantly in the CG $(\mathrm{p}>0.05)$. It indicates by far better effect of the classes in specialized clubs in strength sports on the physical development of students - future doctors.

The analysis of the vital lung capacity showed that a significant difference between the indicators of the EG and CG students was not detected in the 1st - 3rd terms of study $(\mathrm{p}>0.05)$. It was recorded only in the 4 th term $-271.9 \mathrm{ml}$ $(\mathrm{p}<0.05)$ (Table II). The investigation of the vital capacity dynamics indicates that the indicators of the respiratory system significantly improved during training in both groups, but the difference between the indicators of the 1st and 4th terms was $444.9 \mathrm{ml}$ in the EG $(\mathrm{p}<0.001)$, and $194.7 \mathrm{ml}$ in the $(p<0.05)$ that proves the positive effect of sports on the functional abilities of the respiratory system of students.

The analysis of resting heart rate shows that a significant difference between the indicators of the EG and CG students was not detected in the 1st - 3rd terms of study $(\mathrm{p}>0.05)$. In the 4 th term, the heart rate of the EG students was 2.6 beats/min better than that of the CG students authentically $(p<0.05)$ (Table III). During the study, the heart rate of the students of both groups tended to improve. However, the indicators improved by 2.3 beats $/ \mathrm{min}$ in the $\mathrm{EG}$, and only by 0.4 beats/min in the CG $(\mathrm{p}>0.05)$.

The study of blood pressure points put that the indicators of both systolic and diastolic pressure were the same for the EG and CG students authentically in the 1st-4th terms of study ( $>0.05$ ) (Table III). During the research, the blood pressure of the EG students had a tendency to improve, but the indicators did not change authentically $(p>0.05)$.

The analysis of body mass index stated no significant difference between the indicators of the EG and CG stu- dents during the whole study ( $>00.05)$ (Table IV). The investigation of the dynamics of the body mass index shows that body mass index was deteriorating in the CG, the worst value was recorded in the 4 th term $\left(24.20 \mathrm{~kg} / \mathrm{m}^{2}\right)$. The index was stable in the EG during all terms of study that confirmed the positive influence of sports, in contrast to classes according to the current program of physical education. The evaluation of the body mass index proved that in accordance with Table I, the index of the students of both groups was within normal limits. However, given the negative dynamics of the body mass index of the CG students, it can be argued that this index will continue to deteriorate in the senior years of studying.

The analysis of the life index showed that no significant difference between the indicators of the EG and CG students was found in the 1st and 2nd terms of study ( $p>0.05)$. The life index of the EG students was significantly better than that of the CG students by $4.94 \mathrm{ml} / \mathrm{kg}(\mathrm{p}<0.05)$ in the $3 \mathrm{rd}$ term and by $6.88 \mathrm{ml} / \mathrm{kg}(\mathrm{p}<0.001)$ in the 4 th term (Table IV). During the study period, the life index of the EG students improved by $5.68 \mathrm{ml} / \mathrm{kg}$ authentically $(\mathrm{p}<0.05)$, and the index of the CG students worsened not authentically $(\mathrm{p}>0.05)$. According to Table I, the life index in the CG was assessed as below the middle at all stages of the study, and in the EG it was assessed as the middle in the 1 st - 3rd terms, and above the middle in the 4 th term. It indicates a positive impact of sports on the performance of students' respiratory systems.

The analysis of the power index showed that the power index in the EG and CG did not differ authentically in the 1 st and 2 nd terms of study ( $p>0.05)$. In the 3rd term, the power index of the EG students was significantly better in comparison with the CG students' by $5.78 \%(\mathrm{p}<0.05)$, in the 4 th term - by $10.37 \%(\mathrm{p}<0.001)$ (Table IV). During 
Table IV. Comparative characteristics of the EG and CG students' physical health while studying at a medical university (Mean \pm SD)

\begin{tabular}{|c|c|c|c|}
\hline Terms of study & $E G(n=40)$ & CG $(n=320)$ & Significance value \\
\hline \multicolumn{4}{|c|}{$\mathrm{BMI}, \mathrm{kg} / \mathrm{m}^{2}$} \\
\hline $1 \mathrm{st}$ & $23.37 \pm 0.48$ & $23.41 \pm 0.28$ & $p>0.05$ \\
\hline 2nd & $23.36 \pm 0.46$ & $23.79 \pm 0.27$ & $p>0.05$ \\
\hline $3 r d$ & $23.36 \pm 0.45$ & $23.95 \pm 0.28$ & $p>0.05$ \\
\hline 4th & $23.35 \pm 0.44$ & $24.20 \pm 0.29$ & $p>0.05$ \\
\hline \multicolumn{4}{|c|}{$\mathrm{Ll}, \mathrm{ml} / \mathrm{kg}$} \\
\hline $1 \mathrm{st}$ & $55.75 \pm 1.72$ & $55.94 \pm 0.63$ & $p>0.05$ \\
\hline 2nd & $57.86 \pm 1.69$ & $55.51 \pm 0.64$ & $p>0.05$ \\
\hline $3 r d$ & $59.91 \pm 1.70$ & $54.97 \pm 0.65$ & $\mathrm{p}<0.01$ \\
\hline 4 th & $61.43 \pm 1.71$ & $54.55 \pm 0.64$ & $p<0.001$ \\
\hline \multicolumn{4}{|c|}{$\mathrm{Pl}, \%$} \\
\hline $1 s t$ & $53.57 \pm 1.89$ & $53.72 \pm 0.91$ & $p>0.05$ \\
\hline 2nd & $56.49 \pm 1.86$ & $53.41 \pm 0.87$ & $p>0.05$ \\
\hline $3 \mathrm{rd}$ & $59.02 \pm 1.88$ & $53.24 \pm 0.88$ & $p<0.01$ \\
\hline 4 th & $63.39 \pm 1.90$ & $53.02 \pm 0.87$ & $\mathrm{p}<0.001$ \\
\hline \multicolumn{4}{|c|}{ Rl, c.u. } \\
\hline $1 \mathrm{st}$ & $85.34 \pm 1.77$ & $85.24 \pm 0.67$ & $p>0.05$ \\
\hline 2nd & $83.49 \pm 1.76$ & $85.46 \pm 0.66$ & $p>0.05$ \\
\hline $3 \mathrm{rd}$ & $83.09 \pm 1.73$ & $85.62 \pm 0.67$ & $p>0.05$ \\
\hline 4 th & $82.31 \pm 1.68$ & $85.71 \pm 0.68$ & $p>0.05$ \\
\hline \multicolumn{4}{|c|}{ HRR, s } \\
\hline $1 s t$ & $137.1 \pm 3.09$ & $134.8 \pm 1.76$ & $p>0.05$ \\
\hline 2nd & $126.3 \pm 3.02$ & $129.7 \pm 1.73$ & $p>0.05$ \\
\hline $3 r d$ & $117.9 \pm 2.97$ & $124.6 \pm 1.71$ & $p>0.05$ \\
\hline 4th & $110.4 \pm 2.93$ & $119.2 \pm 1.70$ & $p<0.05$ \\
\hline \multicolumn{4}{|c|}{ Physical health level, points } \\
\hline $1 s t$ & $1.51 \pm 0.64$ & $1.47 \pm 0.22$ & $p>0.05$ \\
\hline 2nd & $4.98 \pm 0.58$ & $1.78 \pm 0.21$ & $\mathrm{p}<0.001$ \\
\hline $3 r d$ & $7.09 \pm 0.60$ & $2.04 \pm 0.20$ & $p<0.001$ \\
\hline 4th & $7.21 \pm 0.59$ & $2.55 \pm 0.21$ & $\mathrm{p}<0.001$ \\
\hline
\end{tabular}

Legend:Mean - arithmetical average; SD - standard deviation; $p$ - the significance of difference between the indicators of EG and CG due to the Student's t-test

the period of study, the power index improved significantly by $9.82 \%$ in the EG $(\mathrm{p}<0.001)$, and did not change authentically in the CG ( $>0.05)$. It indicates a positive effect of sports on strengthening the organisms of future doctors. The estimation of the power index according to Table I showed that the power index of the CG students corresponded to a low level at all stages of the study, and the index of the EG students - to a low level in the 1st 3rd terms, and below the middle in the 4th term, which emphasizes the advantage of classes in specialized groups in strength sports at the university.

The analysis of the Robinson's index showed that a significant difference between the EG and CG was not detected at all stages of the study $(p>0.05)$. However, during the study, the Robinson's index improved by 3.03 c.u. in the EG, and remained unchanged in the CG (Table IV). It proves a pos- itive impact of sports on improving the functional abilities of the cardiovascular system of students. The evaluation of the Robinson's index defined that the functional abilities reserves of the cardiovascular system of the students of both groups corresponded to the middle level in the 1st term. In all other terms, the Robinson's index was estimated as the middle in the CG, and as above the middle in the EG.

The analysis of heart rate recovery showed that in the 1st - 3rd terms, the indicators of the EG and CG were significantly equal ( $p>0.05$ ). In the 4 th term, the heart rate recovery of the EG students was found to be better than the CG students by $8.8 \mathrm{~s}(\mathrm{p}<0.05)$ (Table IV). The analysis of the dynamics of the cardiovascular system recovery showed that the heart rate recovery improved in both groups, but it accounted for $15.6 \mathrm{~s}$ in the CG $(\mathrm{p}<0.001)$, and $26.7 \mathrm{~s}$ in the EG $(p<0.001)$. It emphasizes the efficiency of sports in 
terms of the improvement of the students' cardiovascular system. The assessment of this parameter in accordance with Table I determined that the heart rate recovery of the CG students corresponded to below the middle level in the 1 st - 3rd terms, and the middle in the 4th term; in the EG the below the middle level was recorded in the 1st and 2 nd terms, the middle level in the 3 rd and 4th terms.

The study of the physical health level showed that the level of health of the EG and CG students was the same authentically only in the 1st term ( $p>0.05)$. At all other stages of the study, the EG students were recorded to have a significantly higher level of physical health than the CG students $(\mathrm{p}<0.001)$ (Table IV). The analysis of the dynamics of physical health showed that there was a tendency for health improvement in both groups. However, the level of health improved by $1 / 08$ points in the CG $(p<0.01)$, and by 5.7 points in the EG $(\mathrm{p}<0.001)$ that confirms the results of many studies $[5,13,17]$ on the positive impact of sports on improving students' health. The assessment of the physical health level of students in accordance with Table I designated that the level of health corresponded to a low level in the CG at all stages of the study, and in $\mathrm{EG}$, it corresponded to a low level in the 1st term, below the middle in the 2nd and 3rd terms, and the middle in the 4 th term.

Thus, the research concludes that strength sports affect physical development, functional abilities of the major systems of an organism, and the health state of future doctors in a more efficient way than the current program of physical education at a medical university. In addition to the development of physical qualities, the morphofunctional development of students and health improvement, physical exercises help increase the body's resistance to adverse factors of educational activities, prevent somatic diseases, prolong active life, increase academic success and professional efficiency of future doctors.

\section{DISCUSSION}

The most important human value is health. Good health and high resistance to adverse environmental factors are the important conditions for active longevity, successful learning, productive professional activities, personal and family happiness. Only a physically, spiritually, and mentally healthy person can realize the potential most effectively and at the same time feel like a sound member of society $[6,8,9]$.

The studies of many scientists $[21,27]$ showed that in the developed countries, the issues of physical education and mass sports among students are of great importance, considering them as the most cost-effective and efficient means of preventing diseases, strengthening the gene pool and solving a number of other social problems. Thus, analyzing the experience of the physical improvement process organization at HEI in Poland, Yu. Voyner [28] found that 120 hours are devoted to physical education classes at most of the state HEI (41\% of universities), which are implemented during the 1st and 2 nd terms of study. About $28 \%$ of Polish HEIs devote 180 hours to solve the tasks of purposeful physical improvement of students, realized during the 1st - 3rd terms of study. As a rule, after completing the compulsory physical education program of the 1st and 2nd years of study, a student continues to attend elective classes in sports clubs. Moreover, there are significant discounts for tuition or increased scholarships for the active members of sports clubs. In the US, the physical education system of students functions mainly by means of sports training in the relevant sports clubs, so a future specialist has the opportunity to develop physical abilities in the chosen sport, which one considers the most interesting and favorable for physical improvement [29]. In China, the initial courses of study necessarily provide for the solution of general physical training tasks, and in the senior courses, physical improvement is carried out by means of sports training [30].

The main purpose of the physical education of the students of Ukrainian HEI is to increase the physical culture of young people, which primarily involves their engagement in an active lifestyle. Currently, the experts have no doubt that the formation of the students' positive motivation for sports directly affects the efficiency of the physical education process $[31,32]$. The conducted research showed that the current system of physical education at HEI of Ukraine is not effective enough to strengthen the health of students. Our results are confirmed by the conclusions of many scientists $[1,4,12]$ who believe that the traditional form of physical education classes leads to a decrease in students' interest in physical education. Many scientists $[7,16,20]$ argue that one of the most relevant forms of physical education organization is a sports-oriented form of training. Each student can choose the sport that is the most suitable and that brings pleasure. It is necessary to take into account the popularity of sports among students, which may be determined by questionnaires, the opportunities, and conditions of sports facilities of a HEI, as well as sports specialists among the teaching staff of the Department of Physical Education.

The investigation of research, aimed at solving the problems of physical education of students [20,21,22], showed that the organization of physical education of students on the basis of their division into groups by interests in sports increases motivation for classes, affects the regularity of their attendance, promotes their health, and increases their physical fitness.

\section{CONCLUSIONS}

The conducted research suggests that strength sports in specialized groups of universities are more effective than the current program of physical education for the physical development, functional abilities of the body's major systems, and the level of physical health of future doctors. It was found that the influence on the indicators of handgrip test, vital capacity, and heart rate of the EG students was the most prominent positive effect of sports. The evaluation of the calculated indexes (power index, life index) and the level 
of physical health confirmed this trend. It was found that the level of physical health, which was determined by the method of Professor Apanasenko, of the EG students was significantly better than that of the CG students' at the end of the study $(\mathrm{p}<0.001)$, and was assessed as the middle in the EG, and as a low in the CG. This asserts the necessity of introducing the sports-oriented form of the physical education organization at the medical HEI of Ukraine to maintain the efficiency of the future doctors' professional activity.

The prospects for future research are aimed at studying the level of physical health of university students - future doctors, who in the process of studying attended sports groups in various sports.

\section{REFERENCES}

1. Prysiazhniuk S., Tolubko V., Oleniev D. et al. The influence of physical activities on biological age parameters of the first-year female students from the special medical department. Journal of Physical Education and Sport. 2018; 18(2): 561-564. doi:10.7752/jpes.2018.02081.

2. Melnychukl., Fedchyshyn N., Pylypyshyn 0., Vykhrushch A. Philosophical and cultural aspects of medical profession philosophical and conceptual peculiarities. Cultura International Journal of Philosophy of Culture and Axiology. 2019; 16(1): 165-174.

3. Prontenko K., Griban G., Dovgan N. et al. Students' health and its interrelation with physical fitness level. Sport Mont. 2019; 17(3): 41-46. doi 10.26773/smj.191018.

4. Griban G., Lyakhova N., Tymoshenko 0. Current state of students' health and its improvement in the process of physical education. Wiad. Lek. 2020; 73(7): 1438-1447. doi: 10.36740/WLek202007124.

5. Mozolev 0., Bloshchynsky l., Alieksieiev 0. et al. Influence of modern fitness technologies on the state of health and development of motor abilities of 17-19-year-old female students. Journal of Physical Education and Sport. 2019; 19(Supplement issue 3): 917-924. doi:10.7752/jpes.2019.s3132.

6. Vilenskiy M.Ya. Sotsialno-psihologicheskie determinantyi formirovaniya zdorovogo obraza zhizni [Socio-psychological determinants of a healthy lifestyle]. Teoriya i praktika fizicheskoy kulturyi. 1994; 9: 9-11. (In Russian).

7. Essaw E., Moses M. O., Afrifa D. et al. Physical activity patterns and dietary habits of undergraduate students. Baltic Journal of Health and Physical Activity. 2019; 11(1): 115-123. doi: 10.29359/BJHPA.11.1.12.

8. Kosiba G., Gacek M., Wojtowicz A., Majer M. Level of knowledge regarding health as well as health education and pro-health behaviours among students of physical education and other teaching specializations. Baltic Journal of Health and Physical Activity. 2019; 11(1): 83-95. doi: 10.29359/BJHPA.11.1.09

9. Budagh'janc Gh. M. Zdorovyj sposib zhyttja - osnovna umova profilaktyky deviantnoji povedinky pidlitka (istorychnyj aspekt) [Healthy lifestyle - the main condition for the prevention of adolescent deviant behavior (historical aspect)]. Pedaghoghika, psykhologhija ta medykobiologhichni problemy fizychnogho vykhovannja i sportu. 2010; 6: 25-28. (In Ukrainian).

10. Malimon 0., Volchinskiy A. Dinamika zahvoryuvanosti ta stanu zdorov'ya studentiv [Dynamics of student morbidity and health]. Fizichne vihovannya, sport i kultura zdorov'ya u suchasnomu suspilstvi. 2005; 1: 286-289. (In Ukrainian).

11. Apanasenko G. L. Knygha o zdorovj'e [Health Book]. Kyev: Medknygha. 2007: 132. (In Russian).
12. Prontenko K., Griban G., Aloshyna A. et al. The physical development and functional state as the important components of the students' health. Wiad. Lek. 2019; 72(12a):2348-2353. doi: 10.36740/WLek201912115.

13. Zavydivska 0., Zavydivska N., Khanikiants 0 . Self-management as a condition for creating a health culture among students. Journal of Physical Education and Sport. 2016; 16(1):592-597. doi:10.7752/jpes.2016.s1093.

14. Muntjan V.S. Analyz faktorov, opredeljajushhykh zdorovj'e cheloveka y okazyvajushhykh na negho vlyjanyja [Analysis of factors that determine human health and influence it]. Fyzycheskoe vospytanye studentov. 2010; 6: 44-47. (In Russian).

15. Gruzieva T., Galiienko L., Pelo I. et al. Health and lifestyle of students' youth: status, problems and ways of solution. Wiad Lek. 2018; 71(9): 1753-1758.

16. Griban G., Tymoshenko 0., ArefievV. et al. The role of physical education in improving the health status of students of special medical groups. Wiad. Lek. 2020; 73 (3): 534-540. doi: 10.36740/WLek202003125.

17. Zhamardiy V., Shkola 0., Okhrimenko I. et al. Checking of the methodical system efficiency of fitness technologies application in students' physical education. Wiad Lek. 2020; 73 (2), 332-341. doi: 10.36740/ WLek202002125.

18. Bolotin A., Bakayev V. Structure and content of the educational technology of managing students' healthy lifestyle. Journal of Physical Education and Sport. 2015; 15(3): 362-364. doi:10.7752/ jpes.2015.03054.

19. Griban G., Prontenko K., Zhamardiy V. et al. Professional stages of a physical education teacher as determined using fitness technologies. Journal of Physical Education and Sport. 2018; 18(2): 565-569. doi:10.7752/jpes.2018.02082.

20. Prontenko K., Griban G., Bloshchynskyi I. et al. Improvement of students' morpho-functional development and health in the process of sport-oriented physical education. Wiad Lek. 2020; 73(1): 161-168. doi: 10.36740/WLek202001131.

21. Mozolev 0., Khmara M., Shorobura I. et al. Comparative analysis of the effectiveness of Polish and Ukrainian basic training programs in physical education for 9-10-year-old pupils. Universal Journal of Educational Research. 2019; 7(11): 2345-2351. doi: 10.13189/ujer.2019.071112.

22. Griban G., Dikhtiarenko Z., Yeromenko E. et al. (2020). Influence of positive and negative factors on the university students' health. Wiad. Lek. 2020; 73 (8): 1735-1746. doi: 10.36740/WLek202008128.

23. World Health Organization. Global recommendations on physical activity for health. http://www.who.int/dietphysicalactivity/ factsheet_recommendations.

24. Makarov S., Stoyan N., Serheta I., Taran 0. et al. Peculiarities of the interaction of the indicators of psychophysiological adaptation of modern students in the context of the effective monitoring of individual health of young women and young men. Wiad. Lek. 2019; 72 (5a): 1053-1058.

25. Griban G., Yavorska T., Tkachenko P. et al. Motor activity as the basis of a healthy lifestyle of student youth. Wiad. Lek. 2020; 73(6), 1199-1206. doi: 10.36740/WLek202006123.

26. Prontenko K., Bloshchynskyi I., Griban, G. et al. Formation of readiness of future physical culture teachers for professional activity. Universal Journal of Educational Research. 2019; 7(9): 1860-1868. doi: 10.13189/ ujer.2019.070903.

27. Apanasenko G., Dolzhenko L. Rivenj zdorov'ja i fiziologhichni rezervy orghanizmu. [The level of health and physiological reserves of the organism]. Teorija i metodyka fizychnogho vykhovannja i sportu. 2007; 1: 17-21. (In Ukrainian). 
28. Voyner Yu. Sovershenstvovanie sistemyi fizicheskogo vospitaniya v Polskih vyisshih uchebnyih zavedeniyah [Improvement of the physical education system in Polish higher education institutions]. Mezhdunarodnyiy sbornik nauchnyih trudov. 2000; 1: 25-30. (In Russian).

29. Volkov V. L. Osoblivosti organizatsiyi sportivnoyi ta fizkulturnoozdorovchoyi diyalnosti studentiv vischih navchalnih zakladiv riznih regioniv svitu [Features of the organization of sports and physical culture and health-improving activity of students of higher educational institutions of different regions of the world]. Pedagogika, psihologiya ta mediko-biologichni problemi fizichnogo vihovannya i sportu. 2007; 4: 25-28. (In Ukrainian).

30. Li Cszin. Analiticheskiy obzor programmnyih trebovaniy po fizicheskomu vospitaniyu v vuzah Kitaya i Ukrainyi [An analytical review of the program requirements for physical education in universities in China and Ukraine]. Slobozhanskiy naukovo-sportivniy visnik. 2006; 9: 167-169. (In Russian).

31. Warburton D., Nicol C. W., Bredin S. S. D. Health benefits of physical activity: the evidence. Canadian Medical Association Journal. 2006; 174: 801-809.

32. Maglovanyi A. V. Osnovy informacijnogho polja zdorov'ja osobystosti [Basics of information field of personality health]. Visnyk Chernighivsjkogho nacionaljnogho pedaghoghichnogho universytetu imeni T. Gh. Shevchenka. Serija: Pedaghoghichni nauky. Fizychne vykhovannja ta sport. 2010; 81: 285-289. (In Ukrainian).
The work was carried out according to the research work of I. Horbachevsky Ternopil National Medical University for 2019-2021 on the theme of "Professional training of future specialists in the medical field on the basis of interdisciplinary integration" (state registration number 0116U004031).

\section{ORCID and contibutionship:}

Iryna M. Melnychuk: 0000-0001-5527-0655

Svitlana O. Yastremska: 0000-0001-6124-4285

Dariya V. Popovych: 0000-0002-5142-2057 ${ }^{B, C}$

Vasyl V. Humeniuk: 0000-0003-2736-3875 D,E

Oksana V. Yefremova: 0000-0002-5149-2151 $1^{E, F}$

LiubovV. Novakova: 0000-0001-7607-7598

Oksana V. Shukatka: 0000-0002-2297-4709 ${ }^{A, B}$

\section{Conflict of interest:}

The Authors declare no conflict of interest.

\section{CORRESPONDING AUTHOR} Iryna M. Melnychuk

I.Horbachevsky Ternopil National Medical University,

1 Maidan Volia st., 46002 Ternopil, Ukraine

tel: +3096-899-05-10

e-mail: ir.melnychuk@gmail.com

Received: 07.08 .2020

Accepted: 05.01.2021

A - Work concept and design, B - Data collection and analysis, C - Responsibility for statistical analysis,

D-Writing the article, $\mathbf{E}$-Critical review, $\mathbf{F}$ - Final approval of the article 